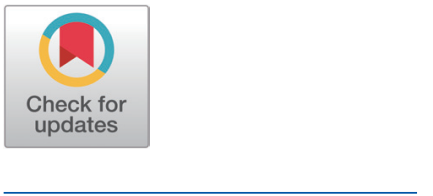

Received: Sep 23, 2020

Revised: Oct 21, 2020

Accepted: Oct 21, 2020

\#These authors contributed equally to this work.

${ }^{*}$ Corresponding author Hyeun Bum Kim

Department of Animal Resources

Science, Dankook University,

Cheonan 31116, Korea

Tel: +82-41-550-3653

E-mail: hbkim@dankook.ac.kr

Minho Song

Division of Animal and Dairy Science, Chungnam National University,

Daejeon 34134, Korea

Tel: +82-42-821-5776

E-mail: mhsong@cnu.ac.kr

Copyright () 2021 Korean Society of Animal Sciences and Technology.

This is an Open Access article distributed under the terms of the Creative Commons Attribution

Non-Commercial License (http:// creativecommons.org/licenses/bync/4.0/) which permits unrestricted non-commercial use, distribution, and reproduction in any medium, provided the original work is properly cited.

ORCID

Sheena Kim

https://orcid.org/0000-0002-5410-1347 Jin Ho Cho

https://orcid.org/0000-0001-7151-0778

Hyeun Bum Kim

https://orcid.org/0000-0003-1366-6090

Minho Song

https://orcid.org/0000-0002-4515-5212

Competing interests

No potential conflict of interest relevant to this article was reported.

Funding sources

This work was carried out with the

\section{Rice as an alternative feed ingredient in swine diets}

\author{
Sheena Kim ${ }^{1 \#}$, Jin Ho Cho ${ }^{2 \#}$, Hyeun Bum Kim ${ }^{1 *}$ and Minho Song ${ }^{3 *}$ \\ ${ }^{1}$ Department of Animal Resources Science, Dankook University, Cheonan 31116, Korea \\ ${ }^{2}$ Division of Food and Animal Science, Chungbuk National University, Cheongju 28644, Korea \\ ${ }^{3}$ Division of Animal and Dairy Science, Chungnam National University, Daejeon 34134, Korea
}

\begin{abstract}
It has become important to explore alternative feed ingredients to reduce feed costs, which are burdensome for livestock production. In addition, it is desirable to find efficient and functional alternative ingredients for traditional feed ingredients in pig diets, considering the stress and sensitivity of disease of pig. Rice is produced around the world like corn that is the typical energy source in pig diets. Although the nutritional quality varies depending on the degree of milling, rice, except whole grains (paddy rice), contains more starch than corn and its structure and granule size are easier to digest than corn. In addition, the fact that rice has fewer non-starch polysaccharides (NSP) and anti-nutritional factors (ANFs) is also effective in improving digestibility and various polyphenols in rice can help modulation of immune responses, which can be beneficial to the gastrointestinal environment and health of pig. Many studies have been conducted on rice focusing on things such as degree of milling, substitution rates of corn, granule size, and processing methods. Most results have shown that rice can be partially or completely used to replace corn in pig diets without negatively affecting pig growth and production. While further research should focus on the precise biological mechanisms at play, it was confirmed that the use of rice could reduce the use of antibiotics and pig removal and protect pigs from gastrointestinal diseases including diarrhea. From this point of view, rice can be evaluated as a valuable feed ingredient for swine diets.
\end{abstract}

Keywords: Alternatives, Corn, Nutrient value, Pig, Rice

\section{INTRODUCTION}

In the animal production industry, it has become important to explore and research alternative feedstock for cost-effective animal production due to the rising cost of feed [1]. It is needed to find efficient alternative ingredients to replace traditional feed ingredients in swine diets. There have been many attempts to find alternative feed ingredients as energy sources in pig diets with competitive feed costs [2-4]. As a result, several candidates including distillers dried grains with solubles, copra meal, palm kernel expellers, and other by-products have been identified as alternatives to replace corn $[5,6]$. While the proposed alternatives have the advantages of being able to supply energy at efficient prices, they tend to contain numerous fibers that are difficult for pigs to digest and rely heavily on imports [7-9].

Post-weaning stress, a major challenging event in swine production, is one of the most important factors of high mortality and morbidity in nursery pigs $[10,11]$. The weaning stress also leads to reduced 
support of 'Cooperative Research Program for Agriculture Science \& Technology Development (Project No. PJ014916052021)' Rural Development Administration, Korea.

Acknowledgements Not applicable.

Availability of data and material Upon reasonable request, the datasets of this study can be available from the corresponding author.

Authors' contributions Conceptualization: Kim S, Song M. Writing - original draft: Kim S, Cho JH Writing - review \& editing: Kim HB, Song M.

Ethics approval and consent to participate This article does not require IRB/IACUC approval because there are no human and animal participants. feed intake, poor growth, and increased susceptibility to diseases $[12,13]$ and causes dramatic changes in intestinal physiology and immunology [14-16]. Immaturity in the immune system of weaned pigs can act the immune responses insufficiently against various pathogens and increase the sensitivity of weaned pigs to disease [17]. Thus, it is necessary to develop diets that are not only highly digestible but one that also has functional ingredients.

Rice is a seed of grass species widely cultivated as a source of foods and the world's third most grown staple crop with 741.5 million tons being produced annually, providing 50 percent of the world's calories along with corn and wheat $[18,19]$. Rice is an excellent source of carbohydrates and contains higher starch and the most useful NSP for human than corn. However, it is more expensive than other grains $[20,21]$ and thus the use of rice as an animal feed ingredient has been restricted.

Current changes in eating habits has led to increased consumption of bread, meat, and fruits instead of rice [22], but rice production has gradually increased with the development of agricultural technology. Due to the changes, the stock of rice has increased [23]. Therefore, there have been many attempts to use rice and their by-product as animal feed ingredients. It may be independent of import of main animal feed ingredients, such as corn and etc., and highly applicable to swine industry if rice can be used as an energy source in swine diets.

The types of rice differ depending on cultivation area and variety. The products produced according to the processing stage are largely divided into whole grain (paddy rice), unpolished rice, polished rice, and their byproducts including rice bran, broken rice, and etc. [24]. Therefore, the nutritional value of rice in swine production will be reviewed in this study.

\section{PHYSICOCHEMICAL FEATURES OF RICE}

The physical structures of grains play an important role in preventing the loss/destruction of nutrients in the grains from internal and external factors during storage [25] and contribute to chemical properties and decomposition of nutrients during digestion [26,27].

The seed of rice is a form of wrapping caryopsis with palea and lemma, which is a husk (hull) with one spikelet [28]. The hull protects rice inside and prevents infestation of fungi and pests from outside. Whole grain rice consists of husk, seed coat, nucleus, endosperm, and embryo (germ) and brown rice is produced when the hull is removed from whole grain rice in first processing. After milling brown rice, germ and rice bran are removed and white starch layer remains, which is referred to as white rice (polished rice). When making the white rice from brown rice, $10 \%$ of rice weight is lost. The weight ratio of each part constituting rice is slightly different according to different types of cultivar. In general, paddy rice consists of rice hull (16-26\%), germ (1.5-2.5\%), bran (3.8-6.7\%), and endosperm (64.8-79.7\%) [29]. There are variations of rice depending on region and cultivar. In addition, rice is available with a variety of colors such as white, red, purple, and black as the pigments in pericarp determines the colors of rice grain [28].

Rice appears to be used as an animal feedstuff since rice includes more starch compared with other conventional cereal grains [30]. However, paddy rice cannot be a feed ingredient in mono-gastric animals since $20 \%$ of the weight of paddy rice is rice hull which are composed of considerable amounts of crude fiber such as lignin and silica [31,32] (Fig. 1).

\section{NUTRITIONAL COMPOSITION OF RICE}

Nutritional composition of rice varies depending on subspecies (e.g., Indica, Japonica, and etc.), climate, soil, and cultivation methods. The amount of white rice, brown rice, germ, and bran 


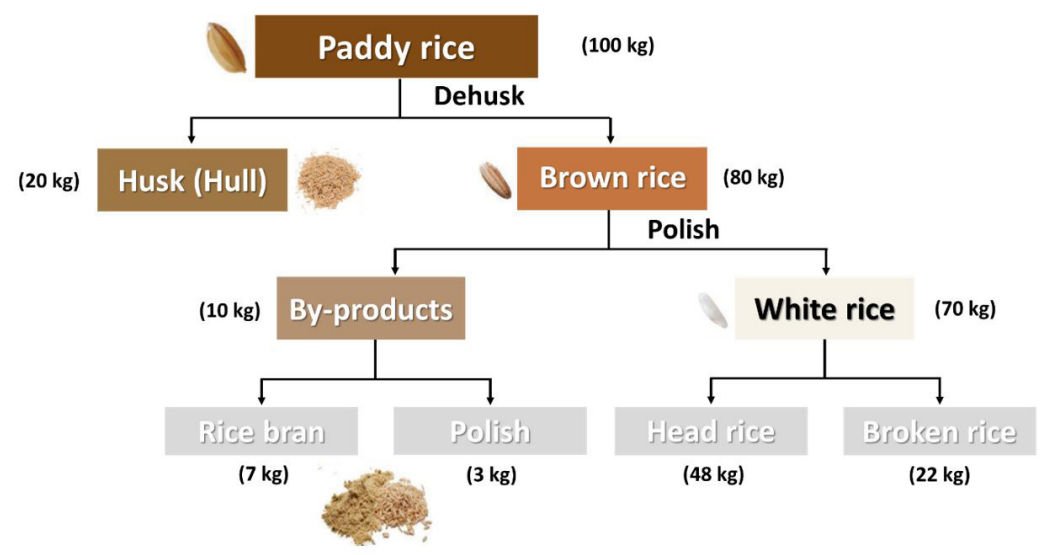

Fig. 1. Product fractions from standard milling process of rice (Source: modified from [31] with public domain).

produced from whole grain rice varies depending on degree of milling. Major nutrient components of brown rice and white rice are carbohydrates (70-90\%), protein (7-8\%), and fat (1-2\%) and most of the carbohydrates are starch contents [33,34]. In addition, gross energy of brown rice and white rice is approximately $3,700 \mathrm{kcal}$ per kilogram [34].

White rice contains high digestible nutrients with low fiber contents compared to other rice products. Compared to white rice, brown rice has been known to have relatively lower carbohydrates and higher protein, fat, and vitamins because it contains bran and germ [34].

Major components of rice bran are carbohydrates (35-40\%), crude protein (10-15\%), and crude fat (15-20\%) [34] as well as vitamins and minerals, especially abundant vitamin B groups and phosphate [34]. However, there are many NSP in rice bran, which is difficult for pigs to digest [35]. Thus, in terms of digestion and utilization by pigs, white rice has almost $25 \%$ higher nutritional values than rice bran [36].

Rice germ contains approximately $28 \%, 20 \%$, and $18 \%$ of carbohydrates, fat, and crude protein, respectively, and is rich in vitamin B groups and phosphate compounds [37,38]. Rice germ also has excellent nutritional values as a feed ingredient for swine diets, but occupies a very small portion in rice and has poor stability during storage due to the presence of highly active lipoxygenase [31]. Therefore, rice germ is stored by blocking contact with oxygen in the form of whole grains to minimize oxidative rancidity reaction and maintain the nutrients.

Starch is a natural polymeric carbohydrate in which many glucose units are connected by $\alpha$-glycoside bond $[39,40]$. It is essentially made from two structurally different polymers such as amylose (linear; $\alpha-1,4)$ and amylopectin (branched; $\alpha-1,4$ and $\alpha-1,6)$. Depending on plants, starch generally consists of 70-80\% amylopectin and 20-30\% amylose [41]. The molecular size (chain length) of amylose composed $\alpha-1,4-$ glycosidic bonds is smaller than that of amylopectin [40] and easily hydrolyzed by the animal digestive enzymes, e.g., $\alpha$-amylase [39, 43, 44]. Unlike starch, structural polysaccharides such as chitin, cellulose, and peptidoglycan are bound by $\beta$-glycosidic bonds and are highly resistant to hydrolysis. Therefore, it requires microbial enzymes to breakdown [45]. Characteristics of different varieties of rice differ due to the ratio of amylose and amylopectin. The 'waxy' starches contain less than 15\% amylose, 'normal' $20-35 \%$, and 'high amylose' greater than approximately 40\% [46]. In this result, the Indica subspecies are less viscous than the Japonica subspecies because amylose contents in the Indica species (25-30\%) are higher than those in the Japonica subspecies (15-22\%) [47]. Besides, the size of starch granules varies depending on 
plant species [48]. The starch granules in rice are relatively small (approximately $2 \mu \mathrm{m}$ ), while potato starch granules are relatively large (more than $100 \mu \mathrm{m})$ [49].

Rice contains not only various polyphenols (e.g., tocopherol, tocotrienol, and $\gamma$-oryzanol) having an antioxidant function but also $\gamma$-aminobutyric acid which has been known to a bio-active compound $[50,51]$. These compounds have been reported as immune modulators by stimulating innate immunity [52-53]. Therefore, the use of rice as a feed ingredient in pig diets may give pigs therapeutic benefits for many gastrointestinal problems such as diarrhea, gut dysfunction, and inflammatory bowel diseases [54]. The antioxidant and physiologically active ingredients are known to be more present in pigmented rice including brown rice, purple rice, and black rice than in white rice [55] because anthocyanin is present as a pigment in rice bran and tocopherol exists in rice germ $[37,55]$. The ANFs in rice such as phytic acids, trypsin inhibitors, and lectin are low and usually present in rice bran and embryos, but they are easily separated during the milling process [56-58].

\section{FEEDING VALUE OF RICE COMPARED TO CORN}

In terms of various benefits of rice, rice starch has unique flavor and taste, small granules, hypoallergenic property, and easy digestibility [21,59]. Starch granule size of rice can also influence its energy digestibility $[60,61]$. Generally, the larger the starch granules, the smaller the surface area to volume, which leads to less binding to enzymes and consequently reduces its hydrolysis [62-64]. It has been found that the size of starch granules in rice is smaller than that in corn $[46,65]$. Therefore, the digestibility values are supportive of better performance of pigs fed rice than those fed corn $[21,39]$. White rice is a rich and digestible carbohydrate with low fiber contents and has high digestible nutrients compared with corn [36]. Due to these characteristics, white rice has the approximately feeding values $25 \%$ higher than rice bran and $12-15 \%$ higher than corn [36]. It seems, however, a waste to employ the white rice as a feedstuff for animals because the milling process requires higher cost and some nutrients including vitamins and fatty acids can be destroyed by the milling process. On the other hand, paddy rice has a low processing cost, but has too much fiber content that is difficult for pigs to digest. For these reasons, brown rice may be a better feedstuff for pigs than white rice [66]. Compared with corn, brown rice has similar concentrations of gross energy, crude protein, and ether extract and comparatively higher amount of starch, essential amino acids, and fatty [66-70] (Table 1).

\section{APPLICATION OF RICE FOR SWINE DIETS}

Compared to various rice by-products, white rice has been studied extensively as a feed component of animal diets (e.g., pigs, poultry). The studies have focused mainly on its particle size [71,72], processing methods [65,73], and substitution rates of corn [74]. Previous studies have shown that white rice can replace some proportions of corn in swine diets without negative effects on growth performance and nutrient digestibility of pigs $[20,41,71,75]$. However, several studies showed that the digestibility of rice was increased compared with that of other grains when rice was heat-treated and fed to pigs in a gelatinous form $[59,65,76]$. In particular, it has been known that cooked white rice can protect pigs from swine dysentery by reducing the substrates for bacterial fermentation in the large intestine [76]. It may have a significant impact on the gastrointestinal environments such as nutritional absorption and microbial balance and population. Similarly, a study showed that the pig removal and antibiotic treatment rate of pigs fed to rice was lower than those of corn [74]. A1though previous studies have focused on white rice mainly, there has been some experiments with brown rice to replace corn in pig diets. Previous studies showed that the partial or complete replace- 
Table 1. Proximate composition of corn, brown rice, and white rice (as-fed basis) ${ }^{1)}$

\begin{tabular}{lccc}
\hline \multicolumn{1}{c}{ Item } & Corn $^{2)}$ & Brown rice $^{3)}$ & White rice $^{4)}$ \\
\hline Gross energy (Mcal/kg) & $3,930(38.08)$ & $3,810(112.39)$ & $3,976(155.13)$ \\
Crude protein (\%) & $8.33(0.36)$ & $8.31(0.39)$ & $8.05(0.07)$ \\
Ether extract (\%) & $3.10(0.39)$ & $2.44(0.26)$ & $1.16(0.36)$ \\
Acid detergent fiber (\%) & $2.90(0.01)$ & $1.31(0.00)$ & $1.85(1.77)$ \\
Crude ash (\%) & $1.19(0.13)$ & $1.05(0.15)$ & $0.66(0.22)$ \\
Total starch (\%) & $60.96(1.58)$ & $72.40(0.00)$ & $79.45(5.86)$ \\
Calcium (\%) & $0.02(0.00)$ & $0.03(0.00)$ & $0.04(0.00)$ \\
Total phosphorus (\%) & $0.28(0.02)$ & $0.33(0.01)$ & $0.18(0.00)$ \\
Moisture (\%) & $12.07(0.26)$ & $12.10(0.00)$ & $12.55(0.64)$ \\
Essential amino acids (\%) & & & \\
Arginine & $0.39(0.03)$ & $0.77(0.00)$ & $0.62(0.14)$ \\
Histidine & $0.26(0.02)$ & $0.16(0.06)$ & $0.22(0.05)$ \\
Isoleucine & $0.30(0.02)$ & $0.38(0.00)$ & $0.37(0.04)$ \\
Leucine & $1.02(0.07)$ & $0.75(0.00)$ & $0.71(0.05)$ \\
Lysine & $0.27(0.01)$ & $0.35(0.00)$ & $0.37(0.10)$ \\
Methionine & $0.19(0.01)$ & $0.20(0.00)$ & $0.20(0.03)$ \\
Phenylalanine & $0.43(0.04)$ & $0.51(0.00)$ & $0.43(0.05)$ \\
Threonine & $0.29(0.02)$ & $0.32(0.00)$ & $0.31(0.07)$ \\
Tryptophan & $0.12(0.11)$ & $0.25(0.12)$ & $0.10(0.00)$ \\
Valine & $0.38(0.04)$ & $0.45(0.00)$ & $0.56(0.09)$ \\
\hline
\end{tabular}

${ }^{11}$ Each value is mean (SD).

${ }^{2)}$ Adapted from [66-70].

${ }^{3}$ Adapted from $[41,66,70]$

${ }^{4)}$ Adapted from $[68,69]$.

ment of corn with brown rice in pig diets did not influence negatively growth performance and nutrient digestibility $[21,65,66,77,78]$.

\section{CONCLUSION}

Feed alternatives are needed to stabilize supply and increase self-sufficiency by replacing corn in order to stabilize the rising production costs of pigs. Rice is produced around the world like corn that is the typical energy source in pig diets. Rice also contains more starch and less non-starch polysaccharides and anti-nutritive factors than corn and its structure and granule size are easier to digest than corn. In addition, rice has several components with physiological activities, such as polyphenols, that can be beneficial to the gastrointestinal environment and health of pigs. Based on the previous studies, rice can be partially or completely used to replace corn in pig diets without negatively influencing pig production. However, further studies are needed to verify how rice helps pigs to improve their health. From the points of view, rice can be a valuable feed ingredient for swine diets.

\section{REFERENCES}

1. Wickramasuriya SS, Yi YJ, Yoo J, Kang NK, Heo JM. A review of canola meal as an alternative feed ingredient for ducks. J Anim Sci Technol. 2015;57:1-9. https://doi.org/10.1186/s40781- 
015-0062-4

2. Robison WL. Substitute for corn for growing and fattening pigs. Wooster: Ohio Agricultural Experiment Station; 1939.

3. Stein HH, Shurson GC. Board-invited review: the use and application of distillers dried grains with solubles in swine diets. J Anim Sci. 2009;87:1292-303. https://doi.org/10.2527/jas.20081290

4. Son AR, Shin SY, Kim BG. Standardized total tract digestibility of phosphorus in copra expellers, palm kernel expellers, and cassava root fed to growing pigs. Asian-Australas J Anim Sci. 2013;26:1609-13. https://doi.org/10.5713/ajas.2013.13517

5. Wachenheim CJ, Novak P, DeVuyst EA, Lambert DK. Demand estimation for agricultural processing coproducts. Great Plains Res. 2006;16:85-94. https://www.jstor.org/stable/23779728

6. Hoffman LA, Baker A. Estimating the substitution of distillers' grains for corn and soybean meal in the U.S/ feed complex. Washington, DC: United States Department of Agriculture; 2011. Report No.: FDS-11-I-01.

7. Agunbiade JA, Wiseman J, Cole DJA. Energy and nutrient use of palm kernels, palm kernel meal and palm kernel oil in diets for growing pigs. Anim Feed Sci Technol. 1999;80:165-81. https://doi.org/10.1016/S0377-8401(99)00070-X

8. Kim BG, Lee JH, Jung HJ, Han YK, Park KM, Han IK. Effect of partial replacement of soybean meal with palm kernel meal and copra meal on growth performance, nutrient digestibility and carcass characteristics of finishing pigs. Asian-Australas J Anim Sci. 2001;14:821-30. https://doi.org/10.5713/ajas.2001.821

9. Son AR, Hyun Y, Htoo JK, Kim BG. Amino acid digestibility in copra expellers and palm kernel expellers by growing pigs. Anim Feed Sci Technol. 2014;187:91-7. https://doi.org/10.1016/ j.anifeedsci.2013.09.015

10. Lallès JP, Bosi P, Smidt H, Stokes CR. Weaning: a challenge to gut physiologists. Livest Sci. 2007;108:82-93. https://doi.org/10.1016/j.livsci.2007.01.091

11. Lallès JP. Long term effects of pre- and early postnatal nutrition and environment on the gut.J Anim Sci. 2012;90:421-9. https://doi.org/10.2527/jas.53904

12. Spreeuwenberg MAM, Verdonk JMAJ, Gaskins HR, Verstegen MWA. Small intestine epithelial barrier function is compromised in pigs with low feed intake at weaning. J Nutr. 2001;131:1520-7. https://doi.org/10.1093/jn/131.5.1520

13. Stokes CR, Bailey M, Haverson K, Harris C, Jones P, Inman C, et al. Postnatal development of intestinal immune system in piglets: implications for the process of weaning. Anim Res. 2004;53:325-34. https://doi.org/10.1051/animres:2004020

14. Pluske JR, Hampson DJ, Williams IH. Factors influencing the structure and function of the small intestine in the weaned pig: a review. Livest Prod Sci. 1997;51:215-36. https://doi. org/10.1016/S0301-6226(97)00057-2

15. Blecha F, Kelley KW. Effects of cold and weaning stressors on the antibody-mediated immune response of pigs.J Anim Sci. 1981; 53:439-47. https://doi.org/10.2527/jas1981.532439x

16. Hampson DJ. Alterations in piglet small intestinal structure at weaning. Res Vet Sci. 1986;40:32-40. https://doi.org/10.1016/s0034-5288(18)30482-x

17. Guevarra RB, Lee JH, Lee SH, Seok MJ, Kim DW, Kang BN, et al. Piglet gut microbial shifts early in life: causes and effects. J Anim Sci Biotechnol. 2019;10:1. https://doi.org/10.1186/ s40104-018-0308-3

18. Nadeem M, Anjum FM, Amir RM, Khan MR, Hussain S, Javed MS. An overview of anti-nutritional factors in cereal grains with special reference to wheat-a review. Pak J Food Sci. 
2010;20:54-61.

19. Muthayya S, Sugimoto JD, Montgomery S, Maberly GF. An overview of global rice production, supply, trade, and consumption. Ann N Y Acad Sci. 2014;1324:7-14.

20. Hopwood DE, Pethick DW, Pluske JR, Hampson DJ. Addition of pearl barley to a rice-based diet for newly weaned piglets increases the viscosity of the intestinal contents, reduces starch digestibility and exacerbates post-weaning colibacillosis. Br J Nutr. 2004;92:419-27. https://doi. org/10.1079/bjn20041206

21. Vicente B, Valencia DG, Pérez-Serrano M, Lázaro R, Mateos GG. The effects of feeding rice in substitution of corn and the degree of starch gelatinization of rice on the digestibility of dietary components and productive performance of young pigs. J Anim Sci. 2008;53:325-34. https://doi.org/10.2527/jas.2006-697

22. Abdullah AB, Ito $S$, Adhana K. Estimate of rice consumption in Asian countries and the world towards 2050. In: Proceedings for Workshop and Conference on Rice in the World at Stake; 2006; Los Banos, Philippines.

23. Korea Rural Economic Institute [KREI]. Monthly international grain observation. 2019 [cited 2019 Jun 28]. http://aglook.krei.re.kr/jsp/pc/front/observe/monthlyReport.jsp?ovr_item_ code=OVR0000000073\&prt_ovr_item_code=OVR0000000071

24. Farrell DJ, Hutton K. Rice and rice milling byproducts. In: Thacker PA, Kirkwood RN, editors. Nontraditional feed sources for use in swine production. Boston, MA: Butterworth; 1990. p. 339-53.

25. Prakash BG, Raghavendra KV, Gowthami R, Shashank R. Indigenous practices for eco-friendly storage of food grains and seeds. Adv Plants Agric Res. 2016;3:101-7. https://doi. org/10.15406/apar.2016.03.00101

26. Bornhorst GM, Chang LQ, Rutherfurd SM, Moughan PJ, Singh RP. Gastric emptying rate and chyme characteristics for cooked brown and white rice meals in vivo. J Sci Food Agric. 2013;93:2900-8. https://doi.org/10.1002/jsfa.6160

27. Bornhorst GM, Kostlan K, Singh RP. Particle size distribution of brown and white rice during gastric digestion measured by image analysis. J Food Sci. 2013;78:E1383-91. https://doi. org/10.1111/1750-3841.12228

28. Juliano B, Bechtel D. The rice grain and its gross composition. In: Juliano B. editor. Rice chemistry and technology. 2nd ed. St. Paul: American Association of Cereal Chemists; 1985. p.17-58.

29. Juliano BO. Rice in human nutrition. Rome: Food and Agriculture Organization of the United Nations; 1993.

30. Knudsen KEB. Carbohydrate and lignin contents of plant materials used in animal feeding. Anim Feed Sci Technol. 1997;67:319-38. https://doi.org/10.1016/s0377-8401(97)00009-6

31. Malekian F, Rao RM, Prinyawiwatkul W. Lipase and lipoxygenase activity, functionality, and nutrient losses in rice bran during storage. Baton Rouge, LA: Louisiana State University Agricultural Center; 2000.

32. Serna-Saldivar SO, Cereal grains: properties, processing and nutritional attributes. Boca Raton, FL: CRC Press; 2010.

33. Marsono Y, Topping DL. Complex carbohydrates in australian rice products-influence of microwave cooking and food processing. Food Sci Technol. 1993;26:364-70. https://doi. org/10.1006/fstl.1993.1072

34. Saleh ASM, Wang P, Wang N, Yang L, Xiao Z. Brown rice versus white rice: nutritional quality, potential health benefits, development of food products, and preservation technologies. Compr Revs Food Sci Food Saf. 2019;18:1070-96. https://doi.org/10.1111/1541-4337.12449

35. Marsono Y, Illman RJ, Clarke JM, Trimble RP, Topping DL. Plasma lipids and large bowel 
volatile fatty acids in pigs fed on white rice, brown rice and rice bran. Brit J Nutr. 1993;70:50313. https://doi.org/10.1079/BJN19930144

36. Bray CI. Rice and rice byproducts for fattening swine. Baton Rouge: Louisiana State University; 1943. Louisiana Bulleten No.: 368.

37. Moongngarm A, Daomukda N, Khumpika S. Chemical compositions, phytochemicals, and antioxidant capacity of rice bran, rice bran layer, and rice germ. APCBEE Procedia. 2012;2:739. https://doi.org/10.1016/j.apcbee.2012.06.014

38. Rondanelli M, Miccono A, Peroni G, Nichetti M, Infantino V, Spadaccini D, et al. Rice germ macro- and micronutrients: a new opportunity for the nutraceutics. Nat Prod Res. 2019;1-5. https://doi.org/10.1080/14786419.2019.1660329

39. Singh J, Dartois A, Kaur L. Starch digestibility in food matrix: a review. Trends Food Sci Technol. 2010;21:168-80. https://doi.org/10.1016/j.tifs.2009.12.001

40. Tortoe C, Akonor PT, Koch K, Menzel C, Adofo K. Amylose and amylopectin molecular fractions and chain length distribution of amylopectin in 12 varieties of Ghanaian sweet potato (Ipomoea batatas) flours. Int J Food Prop. 2017;20:3225-33. https://doi.org/10.1080/10942912 .2017 .1283326

41. Zhang D, Li D, Piao XS, Han IK, Yang CJ, Shin IS, et al. Effects of replacing corn with brown rice or brown rice with enzyme on growth performance and nutrient digestibility in growing pigs. Asian-Australas J Anim Sci. 2002;15:1334-40. https://doi.org/10.5713/ajas.2002.1334

42. Martens BMJ, Gerrits WJJ, Bruininx EMAM, Schols HA. Amylopectin structure and crystallinity explains variation in digestion kinetics of starches across botanic sources in an in vitro pig model.J Anim Sci Biotechnol. 2018;9:91. https://doi.org/10.1186/s40104-018-0303-8

43. Bornhorst GM. Breakdown and mixing of brown and white rice during gastric digestion in vivo. Davis, CA: University of California; 2010.

44. Svihus B, Uhlen AK, Harstad OM. Effect of starch granule structure, associated components and processing on nutritive value of cereal starch: a review. Anim Feed Sci Technol. 2005;122:303-20. https://doi.org/10.1016/j.anifeedsci.2005.02.025

45. Black JL. Nutritional value of cereal grains for animals. Chem Aust. 1999;66:7-9.

46. Tester RF, Karkalas J, Qi X. Starch - composition, fine structure and architecture. J Cereal Sci. 2004;39:151-65. https://doi.org/10.1016/j.jcs.2003.12.001

47. Liu Q, Wang Z, Chen X, Cai X, Tang S, Yu H, et al. Stable inheritance of the antisense waxy gene in transgenic rice with reduced amylose level and improved quality. Transgenic Research. 2003;12:71-82. https://doi.org/10.1023/A:1022148824018

48. Shih CH, Lee TT, Kuo WHJ, Yu B. Growth performance and intestinal microflora population of broilers fed aged brown rice. Ann Anim Sci. 2014;14:897-909. https://doi.org/10.2478/ aoas-2014-0048

49. Puncha-arnon S, Pathipanawat W, Puttanlek C, Rungsardthong V, Uttapap D. Effects of relative granule size and gelatinization temperature on paste and gel properties of starch blends. Food Res Int. 2008;41:552-61. https://doi.org/10.1016/j.foodres.2008.03.012

50. Kang BR, Park MJ, Lee HS. Germination dependency of antioxidative activities in brown Rice. J Korean Soc Food Sci Nutr. 2006;35:389-94. https://doi.org/10.3746/jkfn.2006.35.4.389

51. Cho MK, Kim MH, Kang MY. Application of rice polishing by-products to processed rice Food (I): processing aptitude of rice embryo. J East Asian Soc Diet Life. 2008;18:331-6.

52. Teltathum, T. Effect of Gamma Oryzanol in purple glutinous rice bran on immune response in male mice (Mus musculus) [M.S. thesis]. Chiang Mai, Thailand: Chiang Mai University; 2004. p. 155 .

53. Shin SY, Kim HW, Jang HH, Hwang YJ, choe JS, Lim Y, et al. Y-Oryzanol-rich black rice 
bran extract enhances the innate immune response. J Med Food. 2017;20:855-63. https://doi. org/10.1089/jmf.2017.3966

54. Watson RR, Preedey VR, Zibadi S. Wheat and rice in disease prevention and health: benefits, risks and mechanisms of whole grains in health promotion. London: Academic Press; 2014.

55. Boonsit P, Pongpiachan P, Julsrigival S, Karladee D. Gamma oryzanol content in glutinous purple rice landrace varieties. Chiang Mai Univ J Nat Sci 2010;9:151-8.

56. Popova A, Mihaylova D. Antinutrients in plant-based foods: a review. Open Biotechnol J. 2019;13:68-76. https://doi.org/10.2174/1874070701913010068

57. Samtiya M, Aluko RE, Dhewa T. Plant food anti-nutritional factors and their reduction strategies: an overview. Food Prod Process Nutr. 2020;2:6. https://doi.org/10.1186/s43014-0200020-5

58. Villalobos HME, Espinoza EAM. Anti-nutritional factors present in raw, polished rice. Rev. costarric. salud pública. 2007;16:8-12.

59. Samtiya M, Aluko RE, Dhewa T. Plant food anti-nutritional factors and their reduction strategies: an overview. Food Prod Process Nutr. 2020;2:6. https://doi.org/10.1186/s43014-0200020-5

60. Langworthy CF, Deuel HJ. Digestibility of raw rice, arrowroot, canna, cassava, taro, tree-fern, and potato starches. J Biol Chem. 1922;52:251-61.

61. Kaur L, Singh J, McCarthy OJ, Singh H. Physico-chemical, rheological and structural properties of fractionated potato starches. J Food Eng. 2007;82:383-94. https://doi.org/10.1016/ j.jfoodeng.2007.02.059

62. MacGregor AW, Ballance DL. Hydrolysis of large and small starch granules from normal and waxy barley cultivas by alpha-amylases from barley malt. Cereal Chem. 1980;57:397-402.

63. Tester RF, Qi X, Karkalas J. Hydrolysis of native starches with amylases. Anim Feed Sci Technol. 2006;130:39-54. https://doi.org/10.1016/j.anifeedsci.2006.01.016

64. Mateos GG, López E, Latorre MA, Vicente B, Lázaro RP. The effect of inclusion of oat hulls in piglet diets based on raw or cooked rice and maize. Anim Feed Sci Technol. 2007;135:10012. https://doi.org/10.1016/j.anifeedsci.2006.07.006

65. Ai Y, Jane JL. Understanding starch structure and functionality. In: Sjöö M, Nilsson L, editors. Starch in food. Amsterdam: Woodhead; 2018.p. 151-78.

66. Li D, Zhang DF, Piao XS, Han IK, Yang CJ, Li JB, et al. Effects of replacing corn with Chinese brown rice on growth performance and apparent fecal digestibility of nutrients in weanling pigs. Asian-Australas J Anim Sci. 2002;15:1191-7. https://doi.org/10.5713/ajas.2002.1191

67. Hongtrakul K, Goodband RD, Behnke KC, Nelssen JL, Tokach MD, Bergström JR, et al. The effects of extrusion processing of carbohydrate sources on weanling pig performance. J Anim Sci. 1998;76:3034-42. https://doi.org/10.2527/1998.76123034x

68. National Research Council. Nutrient requirements of swine. Washington, DC: The National Academies Press; 2012.

69. Stein HH, Lagos LV, Casas GA. Nutritional value of feed ingredients of plant origin fed to pigs. Anim Feed Sci Technol. 2016;218:33-69. https://doi.org/10.1016/j.anifeedsci.2016.05.003

70. Li XL, Yuan SL, Piao XS, Lai CH, Zang JJ, Ding YH, et al. The nutritional value of brown rice and maize for growing pigs. Asian-Australas J Anim Sci. 2006;19:892-7. https://doi. org/10.5713/ajas.2006.892

71. Marsono Y, Topping DL. Effects of particle size of rice on resistant starch and SCFA of the digesta in caecostomised pigs. Indones Food Nutr Prog. 1999;6:44-50.

72. Ebling PD, Kessler AM, Villanueva AP, Pontalti GC, Farina G, Ribeiro AML. Rice and soy protein isolate in pre-starter diets for broilers. Poult Sci. 2015;94:2744-52. https://doi. 
org/10.3382/ps/pev279

73. Sittiya J, Yamauchi K, Takata K. Effect of replacing corn with whole-grain paddy rice and brown rice in broiler diets on growth performance and intestinal morphology. J Anim Physiol Anim Nutr. 2016;100:381-90. https://doi.org/10.1111/jpn.12357

74. Che TM, Perez VG, Song M, Pettigrew JE. Effect of rice and other cereal grains on growth performance, pig removal, and antibiotic treatment of weaned pigs under commercial conditions. J Anim Sci. 2012;90:4916-24. https://doi.org/10.2527/jas.2011-4916

75. Brestenský M, Nitrayová S, Patráš P, Heger J. Utilization of amino acids of broken rice in growing pigs. J Microbiol Biotechnol Food Sci. 2020;9:347-9.

76. Pluske JR, Siba PM, Pethick DW, Durmic Z, Mullan BP, Hampson DJ. The incidence of swine dysentery in pigs can be reduced by feeding diets that limit the amount of fermentable substrate entering the large intestine. J Nutr. 1996;126:2920-33. https://doi.org/10.1093/ jn/126.11.2920

77. Kim S, Cho JH, Kim Y, Kim HB, Song M. Effects of substitution of corn with ground brown rice on growth performance, nutrient digestibility, and gut microbiota of growing-finishing pigs. Animals. 2021;11:375. https://doi.org/10.3390/ani11020375

78. Cromwell GL, Henry BJ, Scott AL, Gerngross MF, Dusek DL, Fletcher DW. Glufosinate herbicide-tolerant (LibertyLink) rice vs. conventional rice in diets for growing-finishing swine. J Anim Sci. 2005;83:1068-74. https://doi.org/10.2527/2005.8351068x 